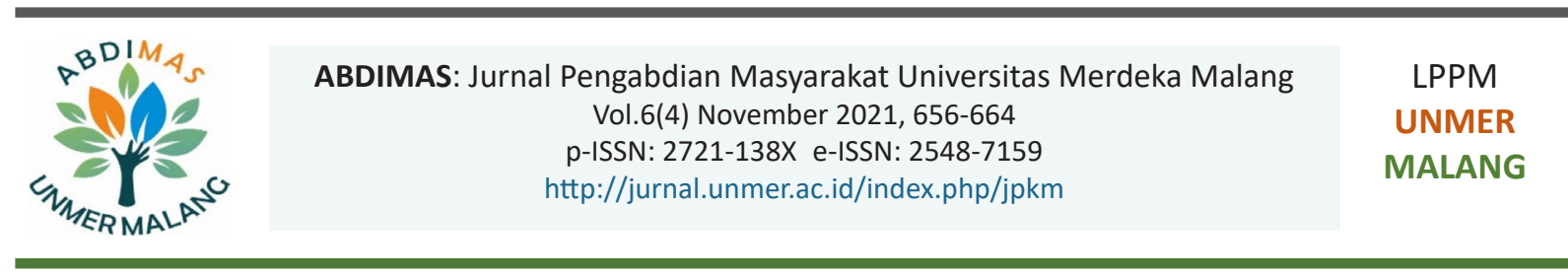

\title{
Formation of an anti-radicalism and terrorism law-aware society
}

\section{Pembentukan masyarakat sadar hukum anti radikalisme dan terorisme}

\author{
Rini Fathonah1, Mashuril Anwar², Maroni Maroni ${ }^{3}$, Nenny Dwi Ariani ${ }^{3}$ \\ ${ }^{1}$ Program Doktor Ilmu Hukum, 2Program Magister Ilmu Hukum, ${ }^{3}$ Fakultas Hukum, Universitas Lampung \\ J. Prof. Dr. Soematri Brojonegoro No.1, Bandar Lampung, 35141, Indonesia
}

ARTICLE INFO
Received: 2021-04-18
Revised: 2021-06-10
Accepted: 2021-08-11
Keywords:
Law-aware, Radicalism,
Terrorism, Youth
organizations

ARTICLE INFO

ABSTRACT

To create harmony and peace in society, every form of radicalism and terrorism must be abolished. Preventing radicalism and terrorism is not easy, because it requires a systematic and massive strategy. The role of the community is very necessary for preventing and overcoming radicalism and terrorism, for that it is important to provide understanding to the community, especially youth organizations. The activity, which was held in Batu Putuk, Teluk Betung Barat, Bandar Lampung, aims to educate and encourage the youth of Karang Taruna, Batu Putuk Village, to play an active role in preventing and overcoming radicalism and terrorism. This activity is carried out with a comprehensive method in the form of socialization, discussion, and clinical services. In line with the aim of the activity, namely educating and encouraging the youth of Karang Taruna in Batu Putuk Village to participate in efforts to prevent radicalism and terrorism, the benefits of this activity include increasing the ability of partners to recognize activities that lead to radicalism and terrorism, increasing the ability of partners to counteract the influence of radicalism and terrorism, as well as encourage the active role of partners in countering radicalism and terrorism.
(C)2021 Published by University of Merdeka Malang. This is an open access article distributed under the CC BY-SA 4.0 license (https://creativecommons.org/licenses/by-sa/4.0/)

How to cite: Fathonah, R., Anwar, M., Maroni, M., \& Ariani, N. D. (2021). Formation of an anti-radicalism and terrorism law-aware society. Abdimas: Jurnal Pengabdian Masyarakat Universitas Merdeka Malang, 6(4), 656-664.

https://doi.org/10.26905/abdimas.v6i4.5714

\section{PENDAHULUAN}

Teror di berbagai tenpat umum dan pusat pelayanan publik akhir-akhir ini menunjukkan Indonesia sedang mengalami krisis moral dan idelologi, sehingga rentan disusupi oleh ideologi asing yang menyesatkan (Wildan, 2019). Pancasila sebagai staat fundamental norm dan UUD RI sebagai grundnorm sedang diuji, terutama kekuatannya dalam meneguhkan rasa persatuan dan menyatukan kemajemukan. Persoalan bangsa ini semakin rumit dan kompleks dengan munculnya berbagai gerakan yang menganut paham radikalisme dan terorisme. Berbagai isu kebangkitan Partai Komunis Indonesia (PKI), negara khilafah (Wibowo, 2020), teror, makar terhadap pemerintahan, gerakan ISIS, dan penghinaan terhadap 
agama kerap kali menjadi pemberitaan. Berbagai gerakan tersebut berakar dari paham radikalisme dan terorisme. Walaupun gerakan tersebut tidak mesti dilakukan dengan kekerasan, namun paham sesat yang diajarkan berpotensi menggangu integrasi bangsa (Khamdan, 2016).

Berdasarkan amanat konstitusi, mewujudkan keamanan, ketentraman, dan ketertiban masyarakat merupakan tanggungjawab negara melalui lembaga-lembaganya. Guna menciptakan kedamaian dan keharmonisan dalam masyarakat, apapun bentuk radikalisme dan terorisme yang berkembang di masyarakat, paham ini harus dicegah dan ditanggulangi. Namun melakukan pencegahan dan penanggulangan paham radikalisme dan terorisme tidak semudah mengatasi kejahatan pada umumnya. Penyebaran paham radikalisme dan terorisme terkadang sulit terdekteksi karena didoktrinisasi melalui berbagai media seperti lembaga pendidikan (Nurhakiky \& Mubarok, 2019), dan organisasi kemasyarakatan (Deshinta, 2017). Oleh karena itu, pencegahan dan penanggulangannya memerlukan strategi yang sistematis dan masif. Agar upaya pencegahan dan penanggulangan radikalisme dan terorisme berlangsung optimal, sinergitas antara penegak hukum dan masyarakat mutlak diperlukan. Masyarakat sipil adalah salah satu kelompok yang kerap menjadi sasaran penyebaran paham sesat ini. Oleh karena itu, penting untuk memberikan pemahaman komprehensif kepada masyarakat terkait paham radikalisme dan terorisme. Pemahaman ini diberikan melalui penanaman nilai Pancasila dan konstitusi sehingga terbentuknya masyarakat sadar hukum (Satriawan et al., 2019).

Sejalan dengan kondisi krisis ideologi Indonesia saat ini, kondisi serupa juga dialami oleh mitra kegiatan ini yaitu pemuda karang taruna Kelurahan Batu Putuk Kota Bandar Lampung. Pada Tahun 2019, Kelurahan Batu Putuk dijadikan lokasi idad (latihan) beberapa teroris yang berbaiat kepada pemimpin ISIS Abu Bakar Albaghdadi. Guna meningkatkan pemahaman ideologi serta mencegah tumbuh suburnya paham radikalisme dan terorisme dalam masyarakat, maka dilakukan sosialisasi sadar hukum di Kelurahan Batu Putuk Kota Bandar Lampung dan organisasi pemuda karang taruna sebagai mitranya. Berdasarkan hasil evaluasi awal, permasalahan mitra dalam hal ini pemuda karang taruna Kelurahan Batu Putuk yakni belum ada pengetahuan dan pemahaman yang cukup terkait upaya pencegahan tumbuh dan berkembangnya radikalisme dan terorisme. Sebagaimana diketahui, pada tahun 2019 Kelurahan Batu Putuk sempat dijadikan lokasi idad beberapa teroris atas nama Rico, Adnan, Rifki Montazeri, Aul Putra Daulah Alias Arif Hidayat, dan Yudistira. Akan tetapi tidak memicu tindakan dari masyarakat setempat khususnya kalangan pemuda karang taruna. Padahal kaderisasi radikalisme kerap menyasar pemuda, karena belum stabilnya emosi dan pola pikir adalah penyebabnya. Misalnya insiden terorisme Tahun 2011 di Klaten yang melibatkan tiga orang pelajar (Prasetyo, 2011), pengeboman gereja Oikumene Tahun 2016 yang melibatkan dua orang remaja (Weltofa et al., 2017).

Keterlibatan kelompok pemuda dalam berbagai aksi teror di atas setidaknya memberikan gambaran pentingnya peran pemuda sebagai perpanjangan tangan kelompok radikalisme dan terorisme. Kondisi ini tentu cukup rasional, mengingat pemuda yang sebagian besar masih di bawah umur memiliki keringanan tersendiri di hadapan hukum. Selain itu, proses kaderisasi paham radikal terhadap pemuda semakin dipermudah dengan berbagai persoalan sosial, ekonomi, hukum, dan ideologi yang mereka alami. (Bayat, 2016). Berdasarkan ulasan di atas, sosialisasi dan pembentukan masyarakat sadar hukum merupakan solusi untuk mencegah radikalisme dan terorisme di Kelurahan Batu Putuk. Oleh karena itu, kegiatan yang bermitra dengan Kelurahan Batu Putuk Kecamatan Teluk Betung Barat Kota Bandar 
ABDIMAS: Jurnal Pengabdian Masyarakat Universitas Merdeka Malang Volume 6, No. 4, November 2021: 656-664

Lampung ini, bertujuan untuk mengedukasi dan mendorong pemuda Karang Taruna Kelurahan Batu Putuk untuk berpartisipasi dalam upaya pencegahan radikalisme dan terorisme. Kegiatan ini semakin urgen sifatnya karena sebagaimana pendapat Sidney Jones yang memperingatkan bahwa radikalisme dan terorisme adalah ancaman nyata bagi Indonesia. Walaupun harus diakui bahwa radikalisme dan terorisme tidak identik dengan agama manapun, tetapi orang yang mengabdikan dirinya pada radikalisme dan terorisme ini adalah korban doktrinasi sesat. Dengan demikian perlu kita pahami bersama bahwa radikalisme dan terorisme dapat berkembang dimana saja, dengan dalil agama apa saja, dan tidak murni produk barat (Nazir, 2017; Aminah, 2016). Program pengabdian ini bertujuan untuk mengedukasi masyarakat khususnya organisasi kepemudaan, mengenai penanggulangan radikalisme dan terorisme. Selain itu kegiatan ini juga bertujuan untuk mendorong pemuda Karang Taruna Kelurahan Batu Putuk untuk berpartisipasi dalam upaya pencegahan radikalisme dan terorisme

\section{METODE}

Kegiatan pembentukan masyarakat sadar hukum anti radikalisme dan terorisme ini dilaksanakan di Kelurahan Batu Putuk Kota Bandar Lampung dengan Karang Taruna sebagai mitranya. Karang taruna Kelurahan Batu Putuk lebih tepatnya berlokasi di RT. 002, RW. 000. Kegiatan ini dilaksanakan dengan menggunakan metode berikut.

Penyampaian materi oleh tim dalam bentuk ceramah. Melalui ceramah, tim penyuluh menyampaikan materi-materi yang penting untuk diketahui dan dipahami (Suwandono, 2013) oleh pemuda Karang Taruna Kelurahan Batu Putuk terkait pencegahan radikalisme dan terorisme.

Diskusi timbal balik mengenai pencegahan radikalisme dan terorisme. Melalui diskusi terarah dan tanya jawab, tim penyuluh dapat melengkapi materi yang belum jelas sekaligus membantu memberikan masukan atas permasalahan yang dihadapi oleh pemuda Karang Taruna Kelurahan Batu Putuk dalam melakukan pencegahan radikalisme dan terorisme.

Pelayanan Klinis Hukum, dalam metode ini diberikan pula pengetahuan dan pemahaman bagaimana cara bertindak secara hukum jika mengetahui adanya tindak pidana radikalisme dan terorisme.

Secara keseluruhan kegiatan pembentukan masyarakat sadar hukum anti radikalisme dan terorisme pada karang taruna Kelurahan Batu Putuk Teluk Betung Barat, Kota Bandar Lampung, dengan tahapan berikut.

Tahap Persiapan kelengkapan administrasi kegiatan, materi kegiatan, dan peninjauan ke lokasi kegiatan termasuk pula koordinasi dengan Lurah Kelurahan Batu Putuk beserta jajarannya, Camat Teluk Betung Barat, dan pemuda Karang Taruna Kelurahan Batu Putuk. Pelaksanaan persiapan ini dilaksanakan pada tanggal 7 September 2020 yang dikoordinatori oleh Mashuril Anwar.

Tahap Pelaksanaan, bertujuan untuk mendiseminasikan ilmu pengetahuan mengenai pencegahan dan penanggulangan radikalisme dan terorisme pada mitra kegiatan. Pelaksanaan kegiatan dilaksanakan

pada 11 September 2020 yang dikoordinatori oleh Rini Fathonah, dengan tahapan kegiatan sebagai berikut: (a) melakukan evaluasi awal; (b) menyampaikan materi kegiatan; (c) diskusi timbal balik; (d) pelayanan klinis hukum; dan (e) melakukan evaluasi akhir. 


\section{HASIL DAN PEMBAHASAN}

\section{Evaluasi Awal}

Aksi radikalisme dan terorisme dalam tataran aplikasinya tidak mesti dilakukan dalam bentuk tindak kekerasan fisik. Akan tetapi, dapat pula dilakukan melalui cara-cara non kekerasan seperti halnya doktrinasi paham-paham sesat (Nugraha, 2020; Khamdan, 2016). Umumnya dinamika radikalisme dan terorisme dalam masyarakat berupa doktrinasi ajaran-ajaran agama yang kontradiktif dengan ideologi. Guna keharmonisan dalam masyarakat, segala bentuk kegiatan-kegiatan doktrinasi paham radikalisme harus dicegah. Radikalisme dan terorisme adalah salah satu bentuk perbuatan yang dikategorikan sebagai kejahatan luar biasa (extra ordinary crime). Pencegahannya pun harus dengan cara-cara luar biasa, sistematis dan masif. Oleh karena itu, pencegahan merebaknya radikalisme dan terorisme harus disertai dengan pemahaman yang komprehensif mengenai ideologi Pancasila dan nilai-nilai religius (Satriawan et al., 2019).

Kegiatan ini diikuti oleh 20 orang peserta yang berasal dari pemuda karang taruna kelurahan Batuputuk. Sebagian besar peserta masih menjalani studi di Sekolah Menengah Atas (SMA) dan Perguruan Tinggi. Hasil evaluasi awal, pelaksanaan kegiatan, serta evaluasi akhir menunjukkan bahwa kegiatan ini berlangsung lancar dan tertib. Para peserta mengikuti jalannya kegiatan ini dengan hikmat dan seksama. Berdasarkan hasil evaluasi awal, pemuda Karang Taruna Kelurahan Batu Putuk belum mengetahui dan memahami upaya pencegahan radikalisme dan terorisme, serta belum berperan aktif dalam upaya pencegahan radikalisme dan terorisme. Hal ini tentu sangat disayangkan, mengingat pemuda adalah kelompok rentan yang kerap menjadi target kaderisasi paham radikal. Tidak mengherankan memang apabila selama ini pemuda sering menjadi aktor utama dalam berbagai aksi radikalisme dan terorisme. (Prasetyo, 2011).

Pada Tahun 2019 Kelurahan Batu Putuk sempat dijadikan lokasi idad (latihan) beberapa teroris atas nama Rico, Adnan, Rifki Montazeri, Aul Putra Daulah Alias Arif Hidayat, dan Yudistira. Selanjutnya pada Tahun 2016 lalu juga terjadi insiden pengeboman di Samarinda, tepatnya pada gereja Oikumene (Mansur, 2016). Dari insiden ini didapati dua orang pelaku yang berusia 16 dan 17 tahun. Yang lebih memilukan, kedua anak di bawah umur ini juga ikut berperan dalam pembuatan dan perakitan peledak. Berdasarkan data BNPT, lebih dari 52\% narapidana teroris yang menghuni Lembaga Pemasyarakatan berusia 17-34 tahun. Selanjutnya laporan BNPT menunjukkan bahwa pemahaman masyarakat mengenai nilai-nilai keagamaan sebesar 66,3\%, atau tingkat waspada (Seputar Jambi, 2021). Bahkan yang lebih mengkhawatirkan, doktrinasi paham radikalisasi yang menargetkan pemuda, khususnya mahasiswa pada taraf hati-hati. Pada tingkatan ketiga menunjukkan pengurus masjid dan guru sekolah madrasah sebesar berada level bahaya terpapar paham radikal yakni sebesar 15,4\%. Mengingat berbagai persoalan sosial, agama, dan ideologi yang dialami kalangan pemuda Indonesia saat ini, memang kukup beralasan apabila pemuda menjadi sasaran utama dalam proses doktrinasi dan kaderisasi paham radikal Secara bersamaan, Islam radikal menjadi perisai ideologis yang digunakan oleh kaum muda dalam menghadapi keterpinggiran dalam masyarakat serta melindungi diri mereka dari arus deras nilai-nilai dan budaya global (Bayat, 2016). 
ABDIMAS: Jurnal Pengabdian Masyarakat Universitas Merdeka Malang Volume 6, No. 4, November 2021: 656-664

Oleh karena itu, kegiatan Pembentukan Masyarakat Sadar Hukum Anti Radikalisme dan Terorisme pada Karang Taruna Kelurahan Batu Putuk Teluk Betung Barat, Kota Bandar Lampung, dimaksudkan untuk mengedukasi pemuda Karang Taruna Kelurahan Batu Putuk mengenai upaya pencegahan radikalisme dan terorisme serta mendorong pemuda Karang Taruna Kelurahan Batu Putuk untuk berperan aktif dalam upaya pencegahan radikalisme dan terorisme. Berdasarkan hasil evaluasi awal, pemuda karang taruna Batu Putuk memang belum menyadari peran mereka dalam pencegahan radikalisme dan terorisme. Namun, pada kegiatan ini para peserta cukup antusias dan menyimak materi yang disampaikan.

\section{Evaluasi pelaksanaan kegiatan}

Pelaksanaan kegiatan dievaluasi dengan melihat partisipasi dan akurasi peserta dalam menjawab pertanyaan yang diberikan pemateri. Hasil pengamatan menunjukkan bahwa peserta berpartisipasi dengan baik dalam kegiatan ini. Beberapa peserta mengajukan pertanyaan dan mengajak para narasumber untuk berdiskusi serta tanya jawab. Antusiasme peserta cukup tinggi dan menunjukkan keseriusan untuk memahami materi yang dijelaskan. Mengingat para peserta cukup antusias dalam mengikuti kegiatan ini, pemateri yang hadir berkesempatan menyampaikan materi dan memberikan pemahaman kepada para peserta terkait paham radikalisme dan terorisme.

Pemateri menjelaskan bahwa saat ini Indonesia menghadapi kenyataan perang melawan paham radikal dan teroris. Pada saat ancaman teror dan penangkapan pelaku terus berlangsung di Indonesia, disinyalir ada pihak-pihak tertentu yang mengabdikan hidupnya untuk mendoktrinasi orang lain agar menganut paham radikal dan teroris. Ini dilakukan melalui pengajaran ilmu teror dengan menjadikan agama sebagai dasar untuk meyakinkan sasarannya. Berdasarkan fenomena tersebut, diketahui bahwa paham radikal dan teroris tidak murni berasal dari bangsa barat. Fakta menunjukkan bahwa paham sesat ini merebak karena ada yang mengatasnamakan agama untuk memaksa orang yakin untuk bergabung dan memeluk ajaran radikal dan teroris. Radikalisme menekankan pada model sikap dan cara pengungkapan keberagamaan seseorang, sedangkan terorisme merupakan tindakan kriminal yang bertujuan untuk merusakan tatanan keamanan dan ketertiban masyarakat. Bahkan di beberapa negara, aksi-aksi terorisme sengaja dibuat untuk menumbangkan kekuasaan tertentu. Radikalisme lebih menekankan pada persoalan keyakinan, sedangkan terorisme adalah fenomena global dan luar biasa yang memerlukan tindakan luar biasa juga. Namun radikalisme dapat berubah menjadi aksi terorisme, meskipun tidak selalu begitu. Akan tetapi paham radikal sejatinya merupakan tahapan menuju terorisme (Supriadi, 2018; Fanani, 2013).

Selanjutnya dalam pemaparannya pemateri menjelaskan bahwa kemunculan paham radikal di Indonesia tidak secara cuma-cuma. Beberapa kondisi yang menyebabkan munculnya praktik radikalisme antara lain adanya emosi keagamaan, tekanan politik, budaya dan faktor ideologi (Umma, 2012). Sedangkan dalam perspektif politik dan sosial, paham radikal ditimbulkan oleh situasi dan kondisi objektif tertentu yakni adanya dominasi kekuatan ekonomi dan politik yang menyebabkan sulitnya

memperoleh akses keadilan dan kebebasan. Paham radikal juga disebabkan oleh dislokasi atau krisis yang bersifat permanen dalam masyarakat (Umma, 2012). Paham radikal juga ditimbulkan oleh kesenjangan 
dalam masyarakat sehingga menyebabkan hilangnya harapan menyongsong masa depan. Gerakan radikal juga dipengaruhi oleh kesenjangan ekonomi dan sosial. Kesenjangan inilah yang menimbulkan kegalauan dan kecemburuan sosial dalam masyarakat (Finke \& Stark, 2003). Kecemburuan sosial dan ekonomi mendorong seseorang dan kelompok untuk melakukan protes sosial terhadap kondisi yang dihadapinya.

Selanjutnya setelah penjelasan materi, sesi berikutnya dilanjutkan dengan diskusi dan tanya jawab. Pada sesi ini peserta diberikan kesempatan untuk mengajukan 3 (tiga) pertanyaan kepada pemateri. Pertanyaan peserta dalam sesi ini meliputi cara mendeteksi kelompok radikal dan teroris, dan upaya hukum yang dapat dilakukan ketika mengetahui adanya kelompok teroris.
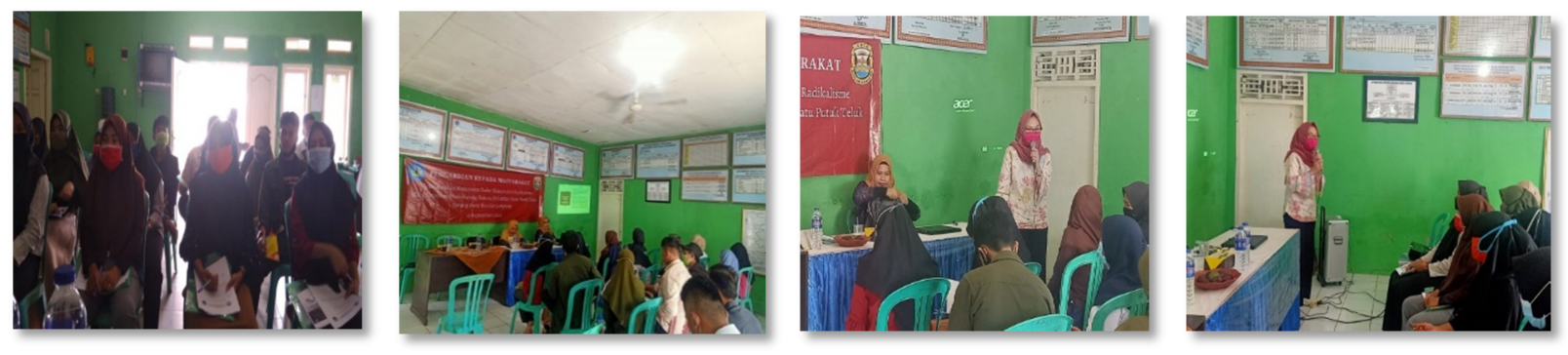

Gambar 1. Peserta kegiatan

Gambar 2. Penyampaian materi

Gambar 3. Sesi tanya jawab

\section{Evaluasi akhir}

Evaluasi akhir dilakukan oleh tim melalui pemberian beberapa pertanyaan kepada peserta terkait penanggulangan gerakan radikalisme dan terorisme di Indonesia. Adapun pertanyaan yang diajukan kepada peserta yaitu: (1) Apa pendapat Anda mengenai doktrin radikalisme dan terorisme?; (2) Menurut Anda, sejauh ini bagaimana keterlibatan pemerintah dan pemerintah daerah dalam menangkal masuknya doktrin radikalisme dan terorisme?; (3) Bagaimana upaya menangkal masuknya doktrin radikalisme dan terorisme di Kelurahan Batuputuk?; (4) Apakah ada sarana prasarana yang mendukung upaya menangkal masuknya doktrin radikalisme dan terorisme di Kelurahan Batuputuk?; (5) Apakah faktor-faktor yang mendukung upaya menangkal masuknya doktrin radikalisme dan terorisme di Kelurahan Batuputuk?

Berdasarkan evaluasi akhir yang dilakukan, pengetahuan dan pemahaman peserta terkait paham radikalisme dan terorisme mengalami peningkatan. Umumnya para peserta berpendapat bahwa paham radikalisme dan terorisme merupakan paham yang menghendaki perubahan secara cepat dan instan sehingga dilakukan melalui teror dan kekerasan yang menimbulkan gangguan keamanan dan berdampak negatif bagi pribadi seseorang. Selanjutnya terkait peran pemerintah dalam penanggulangan radikalisme dan terorisme, sebagian besar peserta berpendapat bahwa peran pemerintah belum optimal sebagaimana Gambar 4.

Selain itu, menurut para peserta terdapat beberapa cara menangkal paham radikal yakni dengan meneguhkan pendirian, membangun pemikiran positif, menanamkan paham nasionalis, dan memberikan sosialisasi kepada masyarakat. Di Kelurahan Batu Putuk sendiri terdapat beberapa faktor 
ABDIMAS: Jurnal Pengabdian Masyarakat Universitas Merdeka Malang Volume 6, No. 4, November 2021: 656-664

yang menyebabkan masuknya paham radikalisme dan terorisme yaitu rendahnya pendidikan pemuda, rumah tangga yang tidak harmonis, minimnya kegiatan positif, rendahnya status ekonomi, penegakan hukum yang kurang tegas, dan minimnya sosialisasi.
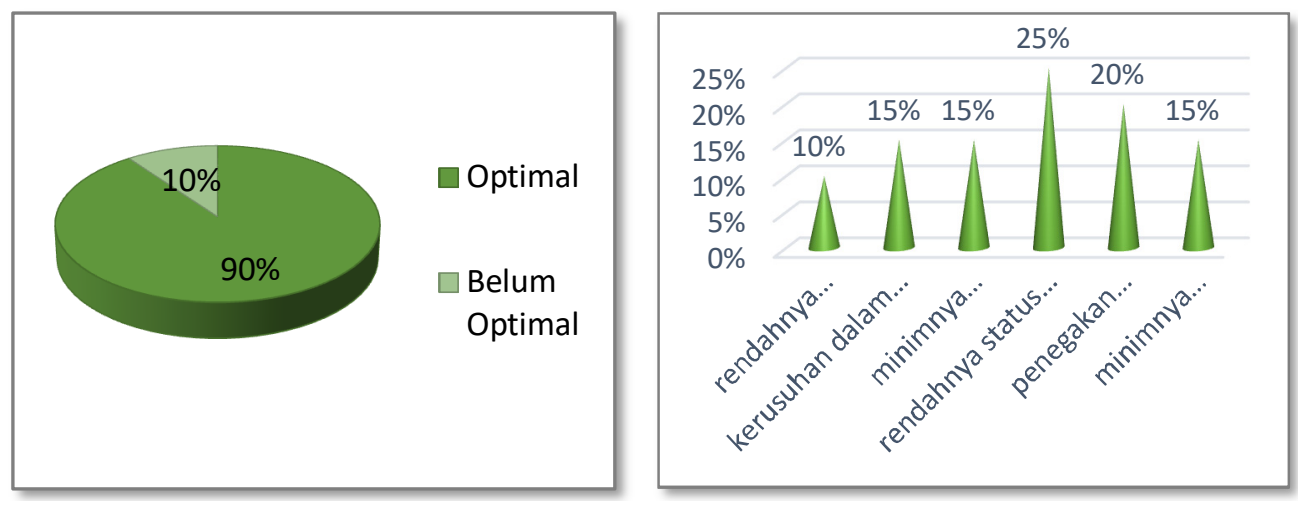

Gambar 4. Pendapat peserta mengenai peran pemerintah dalam penanggulangan radikalisme dan terorisme Gambar 5. Faktor penyebab masuknya paham radikalisme dan terorisme di Kelurahan Batu Putuk

Sejalan dengan tujuan kegiatan yakni mengedukasi dan mendorong pemuda Karang Taruna Kelurahan Batu Putuk untuk berpartisipasi dalam upaya pencegahan radikalisme dan terorisme, manfaat kegiatan ini antara lain: (1) Meningkatkan kemampuan mitra dalam mendeteksi gejala-gejala paham radikal dan teroris. Ketidakcakapan dalam mendeteksi gejala awal akan menjadi peluang masuknya paham radikal dan teroris. Sehingga kemampuan ini menjadi urgen sifatnya untuk dimiliki masyarakat khususnya pemuda (Rapik et al., 2020); (2) Mitra mampu membentengi diri dan menghindari doktrinasi paham radikal dan teroris. Sebagaimana diketahui reaksi negatif ditunjukkan masyarakat terhadap paham radikal dan teror. Akan tetapi dalam tataran praktis, paham radikal dan teroris sangat mudah merasuki kehidupan masyarakat; (3) Melalui kegiatan ini, mitra menunjukkan kesediannya dalam berperan aktif dan bekerja sama dengan aparat penegak hukum dalam mencegah dan menanggulangi segala bentuk gerakan radikal dan terorisme. Selanjutnya yang sangat penting adalah keberanian masyarakat untuk melapor dan kemampuan untuk mendeteksi indikasi keberadaan gerakan radikalisme dan terorisme.

\section{Faktor pendukung dan faktor penghambat kegiatan}

Berdasarkan evaluasi terhadap khalayak sasaran tersebut, faktor penghambat dan pendukung kegiatan ini sebagai berikut: (1) Faktor pendukung. Keberhasilan kegiatan pengabdian ini tak luput dari beberapa faktor pendukung yaitu: (a) Terlaksananya kegiatan ini karena adanya kesediaan Lurah Batu Putuk untuk menyediakan tempat dan waktu pelaksanaan; (b) Adanya kerja sama dan koordinasi yang baik antara tim pengabdian dengan Babinkamtibmas Kelurahan Batu Putuk; (c) Adanya atusiasme peserta dalam menyimak pemaparan materi, diskusi, dan tanya jawab; (d) Adanya rasa keakraban antara tim pengabdian dengan para peserta; (e) Adanya sarana dan prasana yang disediakan oleh Lurah Batu Putuk; (2) Faktor Penghambat. Keberhasilan pelaksanaan kegiatan ini tidak berarti tanpa kendala. 
Berdasarkan hasil identifikasi, ada beberapa hal yang menjadi kendala pelaksanaan kegiatan antara lain keterbatasan waktu, minimnya sarana dan prasarana, dan keterbatasan anggaran.

\section{SIMPULAN DAN SARAN}

Berdasarkan hasil evaluasi pelaksanaan kegiatan, rendahnya pemahaman mitra mengenai pencegahan dan penanggulangan radikalisme dan terorisme disebabkan oleh belum optimalnya sosialisasi yang dilakukan pemerintah. Setelah pelaksanaan kegiatan mitra memahami bahaya gerakan paham radikal dan aksi terorisme, mitra mampu mengantisipasi masuknya paham radikal ke dalam lingkungannya, serta mampu berperan aktif dalam usaha memerangi paham radikal dan aksi terorisme khususnya di lingkungan tempat tinggalnya.

Berdasarkan kesimpulan, untuk memerangi paham radikal dan aksi terorisme diperlukan upayaupaya dari pemerintah untuk menanamkan nilai-nilai Pancasila, nilai luhur keagamaan, dan nilai-nilai luhur budaya nusantara sejak dini. Nilai-nilai luhur ini dapat dilakukan melalui sosialisasi, revitalisasi nilai-nilai luhur tersebut ke dalam kurikulum pendidikan, dan mengefektifkan upaya penguatan wawasan kebangsaan.

\section{DAFTAR PUSTAKA}

Aminah, S. (2016). Peran pemerintah menanggulangi radikalisme dan terorisme di Indonesia. Jurnal Inovasi dan Pembangunan, 4(1), 83-101.

Bayat, A. (2016). Muslim youth and the claim of youthfulness, dalam Tien Rohmatin, nilai-nilai pluralisme dalam Buku Pendidikan Agama Islam (PAl) untuk Sekolah Menengah Atas (SMA). Jurnal Ilmu Ushuluddin, 3(1), 133-152. https://doi.org/10.15408/jiu.v3i1.4857

Deshinta, W. S. (2017). Fungsi pengawasan keimigrasian dalam pengendalian radikalisme pasca penerapan kebijakan bebas visa kunjungan. Seminar Nasional Hukum Universitas Negeri Semarang, 3 (1), 5-28.

Fanani, A. F. (2013). Fenomena radikalisme di kalangan kaum muda. Jurnal Maarif, 8(1), 4-13.

Finke, R., \& Stark, R. (2003). The dynamics of religious economies. Cambridge University Press.

Khamdan, M. (2016). Pengembangan nasionalisme keagamaan sebagai strategi penanganan potensi radikalisme Islam transnasional. Addin, 10(1), 207-232.

http://dx.doi.org/10.21043/addin.v10i1.1135

Mansur, A. (2016, November 14). 'Bom Oikumene' akibat gagalnya pengawasan BNPT. Republika. co.id. https://nasional.republika.co.id/berita/ogmowf384/bom-oikumene-akibat-gagalnyapengawasan-bnpt

Nazir, M. (2017). Peran lembaga pendidikan dan budaya lokal dalam menanggulangi gerakan radikalisme. Al-Fikra: Jurnal Ilmiah Keislaman, 11(1), 1. http://10.24014/af.v11i1.3849

Nugraha, M. S. (2020). Strategi guru aqidah akhlak dalam penanggulangan potensi radikalisme di MAN 1 Kota Sukabumi. Tatar Pasundan: Jurnal Diklat Keagamaan, 13(2). http://10.38075tp.3i2.0 
ABDIMAS: Jurnal Pengabdian Masyarakat Universitas Merdeka Malang Volume 6, No. 4, November 2021: 656-664

Nurhakiky, S. M., \& Mubarok, M. N. (2019). Pendidikan Agama Islam penangkal radikalisme. IQ (Ilmu Al-qur'an): Jurnal Pendidikan Islam, 2(1), 101-116.

Prasetyo, A. (2011, Januari 27). Enam terduga teroris dari satu sekolah. Tempo.co. https://m.tempo.co/read/news/2011/01/27/063309390/enam

Rapik, M., Permatasari, B., \& Anisya, A. (2020). The role of Forum Koordinasi Pencegahan Terorisme in running the deradicalization program. Journal of Political Issues, 1(2), 103-114. https://doi.org/10.33019/jpi.v1i2.11

Satriawan, I, Islami, M. N., \& Lailam, T. (2019). Pencegahan gerakan radikalisme melalui penanaman ideologi pancasila dan budaya sadar konstitusi berbasis komunitas. Jurnal Surya Masyarakat, 1(2), 99-110. https://doi.org/10.26714/jsm.1.2.2019.99-110

Seputar Jambi. (2021, Agustus 8). Identifikasi dan saring informasi di internet, Prof Syukri: Waspada ajakan radikalisme di dunia maya. Seputar Jambi. https://jamberita.com/read/2021/08/08/5968941/ identifikasi-dan-saring-informasi-di-internet-prof-syukri-waspada-ajakan-radikalisme-didunia-maya/

Supriadi, E. (2018). Membangun spirit kebangsaan kaum muda di tengah fenomena radikalisme. Jurnal Sosiologi Agama, 11(1), 1. https://10.14421/jsa.2017.111-01

Suwandono, A., Somawijaya, S., \& Faisal, P. (2013). Pembentukan kelompok masyarakat sadar hukum dan penyuluhan hukum tentang hak-hak konsumen berdasarkan Undang-Undang No. 8 Tahun 1999 tentang perlindungan konsumen di Desa Jalancagak dan Desa Bunihayu Kecamatan Jalancagak Kabupaten Subang. Dharmakarya: Jurnal Aplikasi Ipteks untuk Masyarakat, 2(2), 72-77.

Umma, C. S. (2012). Akar radikalisme Islam di Indonesia. Jurnal Humanika, 12(1), 112-124, https://doi.org/10.21831/hum.v12i1.3657

Wibowo, P. (2020). Sekuritisasi wacana khilafah di Indonesia. Jisiera, 5(1), 25-49, https://doi.org/10.5281/zenodo.4052347

Wildan, M. (2019). Gerakan Fajar Nusantara (GAFATAR): Krisis ideologi \& ancaman kebangsaan. TEMALI: Jurnal Pembangunan Sosial, 2(1), 1-25. https://doi.org/10.15575/jt.v2i1.3479 